\title{
Specific electrical conductivity in molten potassium dihydrogen phosphate KH2PO4 - An electrolyte for water electrolysis at $300^{\circ} \mathrm{C}$
}

Nikiforov, Aleksey Valerievich; Berg, Rolf W.; Petrushina, Irina; Bjerrum, Niels J.

Published in:

Applied Energy

Link to article, DOI:

10.1016/j.apenergy.2016.04.111

Publication date:

2016

Document Version

Peer reviewed version

Link back to DTU Orbit

Citation (APA):

Nikiforov, A. V., Berg, R. W., Petrushina, I., \& Bjerrum, N. J. (2016). Specific electrical conductivity in molten potassium dihydrogen phosphate $\mathrm{KH}_{2} \mathrm{PO}$ - An electrolyte for water electrolysis at $300^{\circ} \mathrm{C}$. Applied Energy, 175 , 545-550. https://doi.org/10.1016/j.apenergy.2016.04.111

\section{General rights}

Copyright and moral rights for the publications made accessible in the public portal are retained by the authors and/or other copyright owners and it is a condition of accessing publications that users recognise and abide by the legal requirements associated with these rights.

- Users may download and print one copy of any publication from the public portal for the purpose of private study or research.

- You may not further distribute the material or use it for any profit-making activity or commercial gain

- You may freely distribute the URL identifying the publication in the public portal 


\title{
Specific electrical conductivity in molten potassium dihydrogen phosphate $\mathrm{KH}_{2} \mathrm{PO}_{4}-$ an electrolyte for water electrolysis at $\sim 300{ }^{\circ} \mathrm{C}$
}

\author{
A. V. Nikiforov ${ }^{a^{*}}$, R. W. Berg ${ }^{b}$, I.M. Petrushina ${ }^{a}$ and N. J. Bjerrum ${ }^{a}$ \\ (a) DTU Energy, Technical University of Denmark, Kemitorvet,207, DK-2800 Kgs. Lyngby, Denmark, nava@dtu.dk, \\ irpe@dtu.dk, nibj@dtu.dk

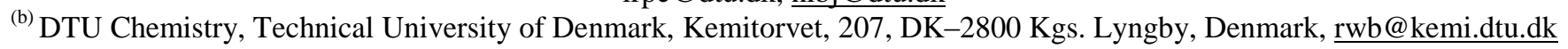

\begin{abstract}
The conductivity of pure molten $\mathrm{KH}_{2} \mathrm{PO}_{4}$ salt and four mixtures with more or less water $\left(\mathrm{KH}_{2} \mathrm{PO}_{4}-\mathrm{H}_{2} \mathrm{O}\right.$ and $\mathrm{KH}_{2} \mathrm{PO}_{4}-\mathrm{KPO}_{3}$

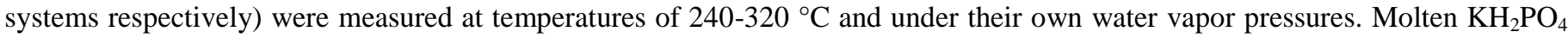
has been proven to be a promising electrolyte for an elevated temperature pressurized water electrolyzer demonstrating high conductivity of $\sim 0.30 \mathrm{~S} \mathrm{~cm}^{-1}$ at $300^{\circ} \mathrm{C}$. The conductivity data are given as polynomial functions of temperature and composition. The melting point of the pure salt under its own water vapor pressure was determined to be $\sim 272{ }^{\circ} \mathrm{C}$.
\end{abstract}

Keywords: Intermediate temperature pressurized water electrolyzer; Molten salt electrolyte; KDP; Elevated temperature water electrolysis; Electrolyte conductivity; Phosphate-based electrolytes.

\section{Introduction}

In the following we will report on the extraordinary conductivity properties of a new liquid, namely molten potassium dihydrogen phosphate $\mathrm{KH}_{2} \mathrm{PO}_{4}$ (or KDP), that has the unusual ability to contain water at temperatures much higher than the normal boiling point of water $\left(\sim 100^{\circ} \mathrm{C}\right)$. This salt has been known and studied for many years and has found various applications [1]. KDP is e.g. one of the most used nonlinear crystals for laser radiation conversion systems, and recently also the application of the melt as the electrolyte for high temperature water electrolysis was suggested [2]. The purpose of the present work was to investigate the level of specific electrical conductivity of the melt, of which there was no previous data available. It was also an objective to determine analytical expressions for the conductivity versus temperature and water content. Such information is essential in the optimization of the high temperature water electrolysis application of the electrolyte. Upon heating, the salt melts and becomes an interesting electrolyte [3]. During the melting process, the following reaction (1) is known to take place [4,5]:

$$
2 \mathrm{KH}_{2} \mathrm{PO}_{4} \leftrightarrow \mathrm{K}_{2} \mathrm{H}_{2} \mathrm{P}_{2} \mathrm{O}_{7}+\mathrm{H}_{2} \mathrm{O} \leftrightarrow 2 / \mathrm{n}\left(\mathrm{KPO}_{3}\right)_{\mathrm{n}}+2 \mathrm{H}_{2} \mathrm{O} \quad(\mathrm{n}=1,2,3, \ldots)
$$

Here the melt loses water by evaporation, starting at $\sim 180{ }^{\circ} \mathrm{C}[6]$ and the melting point drops considerably, from a higher value and perhaps down to earlier reported values of $\sim 253^{\circ} \mathrm{C}[7,8,9]$. However, inspecting the originally published data for the melting point of KDP it seems likely that the given temperatures correspond to the situation, when the decomposition pressure reached one atmosphere [10]. Even more, the melting point was never found to be precisely, as fusion was commencing at $252.6{ }^{\circ} \mathrm{C}$ and being complete at $254.3{ }^{\circ} \mathrm{C}$. There is evidently no true melting point at the open atmospheric pressure, as fusion is simultaneously accompanied by decomposition, with the formation of gaseous water [11]. Further heating of the $\mathrm{K}_{2} \mathrm{H}_{2} \mathrm{P}_{2} \mathrm{O}_{7}-\mathrm{H}_{2} \mathrm{O}$ mixed system under the open atmosphere will unevitably decompose the salt to a metaphosphate and water vapor $[4,5]$ :

$$
\mathrm{KH}_{2} \mathrm{PO}_{4} \rightarrow \mathrm{KPO}_{3}+\mathrm{H}_{2} \mathrm{O}
$$

Accordingly, the melting point of the KDP must be determined in a state, where it is saturated under its own vapor pressure. One way to do this is to place the salt in a closed ampoule, that can stand the considerable water vapor pressure over the molten salt, around 8 bars at $300^{\circ} \mathrm{C}$, according to the recent results, obtained by Raman spectroscopy [3]. The results are different from earlier obtained data [4,5], a clear case which can be explained by the water escaping from the structure of the salt during the experiments, which were performed in open atmosphere and not being saturated by the vapor pressure of the salt, see Equations 1-2. Therefore the following conductivity measurements should be performed under similar pressurized conditions, and accordingly the salt should be placed in a closed conductivity cell.

\section{Materials and Methods}




\subsection{Preparation of the cell}

Well crystallized Monobasic Potassium Phosphate, $\mathrm{KH}_{2} \mathrm{PO}_{4}$ (CAS \#7778-77-0 from Sigma, purity $\geq 99.0 \%$, Pcode 101092922 , PO662-500G, Lot\# 031M0033V, Japan) was used as received (the salt did not lose weight during evacuation at room temperature). $\mathrm{KPO}_{3}$ was prepared by gently heating of weighed $\mathrm{KH}_{2} \mathrm{PO}_{4}$ in a large nickel crucible with a flame until no more water left and then in a furnace for $10 \mathrm{hr}$. at $\sim 600{ }^{\circ} \mathrm{C}$ (the total weight loss was quantitative according to the Equation 2). Cells of a type like those used previously [12] were applied to determine the conductivity $(\sigma)$. The cells were made from fused quartz glass in a glass-blowing workshop and by modifying the contacts of the halogen lamps, see Fig. 1. At first the bulb of the halogen lamp was cut near the base and the tungsten spiral was cut over - thereby creating the two electrodes for the first chamber. A similar operation was done with a similar halogen lamp for the second chamber. Thereafter the whole cell was constructed by placing a prolonged quartz tube on each 2-electrode compartment, connected by a pressure equilibration tube (A, Fig. 1) and a narrow capillary tube for the conduction limitation (C, Fig. 1). The same cell was in some cases used for repeated experiments, after washing out all solidified salt with water under ultrasonic agitation, rinsing with ultrapure water $(\sigma=18 \mathrm{M} \Omega \mathrm{cm})$, drying it in a heating cabinet at $80^{\circ} \mathrm{C}$, and then adding new stems and filling with new chemicals. Five series of measurements were made. The cell constant $K$ for each cell was determined by measuring the resistance $R_{\mathrm{KCl}}(\sim 2.5-4.8 \mathrm{k} \Omega$ depending on the cell number) for a 0.1 Demal aqueous $\mathrm{KCl}$ solution at a precisely known temperature near room temperature according to Jones and Bradshaw [13]. The $R_{\mathrm{KCl}}$ value obtained should be independent of the amount of $\mathrm{KCl}$ solution used. High purity $\mathrm{KCl}$ was used, prepared as described earlier [14].

The experimental series were made with cells, filled with chemicals to make the following compositions, as shown in Table 1 . The composition coefficient, used in the first column was calculated using the Equation 2, where the composition coefficient (or molar ratio between $\mathrm{KPO}_{3}$ and $\mathrm{H}_{2} \mathrm{O}$ equals 1 for pure KDP. For other compositions, the coefficient was lower or higher depending of addition of water or $\mathrm{KPO}_{3}$ correspondingly.

Table 1. Compositions of the salts in the five series.

\begin{tabular}{|c|c|c|c|c|c|c|c|}
\hline $\begin{array}{c}\text { Composition } \\
\text { coefficient } \\
(\text { molar ratio } \\
\left.\mathrm{KPO}_{3} / \mathrm{H}_{2} \mathrm{O}\right)\end{array}$ & $\begin{array}{c}\text { Mass of } \\
\mathrm{KH}_{2} \mathrm{PO}_{4} \\
\mathrm{~g}\end{array}$ & $\begin{array}{c}\text { Molar } \\
\text { amount of } \\
\mathrm{KH}_{2} \mathrm{PO}_{4}, \\
\text { mol } \\
\end{array}$ & $\begin{array}{l}\text { Mass of added } \\
\mathrm{KPO}_{3}, \mathrm{~g}\end{array}$ & $\begin{array}{c}\text { Molar } \\
\text { amount of } \\
\text { added } \\
\mathrm{KPO}_{3}, \text { mol }\end{array}$ & $\begin{array}{c}\text { Mass } \\
\text { of } \\
\text { added } \\
\mathrm{H}_{2} \mathrm{O}, \mathrm{g}\end{array}$ & $\begin{array}{c}\text { Molar } \\
\text { amount of } \\
\text { added } \mathrm{H}_{2} \mathrm{O} \text {, } \\
\text { mol }\end{array}$ & $\begin{array}{c}\text { Molar } \\
\text { percent of } \\
\text { the addition, } \\
\%\end{array}$ \\
\hline 0.97 & 24.78 & 0.182 & - & - & 0.109 & 0.006 & 3.23 \\
\hline 1 & 19.12 & 0.141 & - & - & - & - & - \\
\hline 1.05 & 19.94 & 0.147 & 0.85 & 0.007 & - & - & 4.71 \\
\hline 1.10 & 17.05 & 0.125 & 1.47 & 0.013 & - & - & 9.05 \\
\hline 1.20 & 18.70 & 0.137 & 3.29 & 0.028 & - & - & 16.84 \\
\hline
\end{tabular}




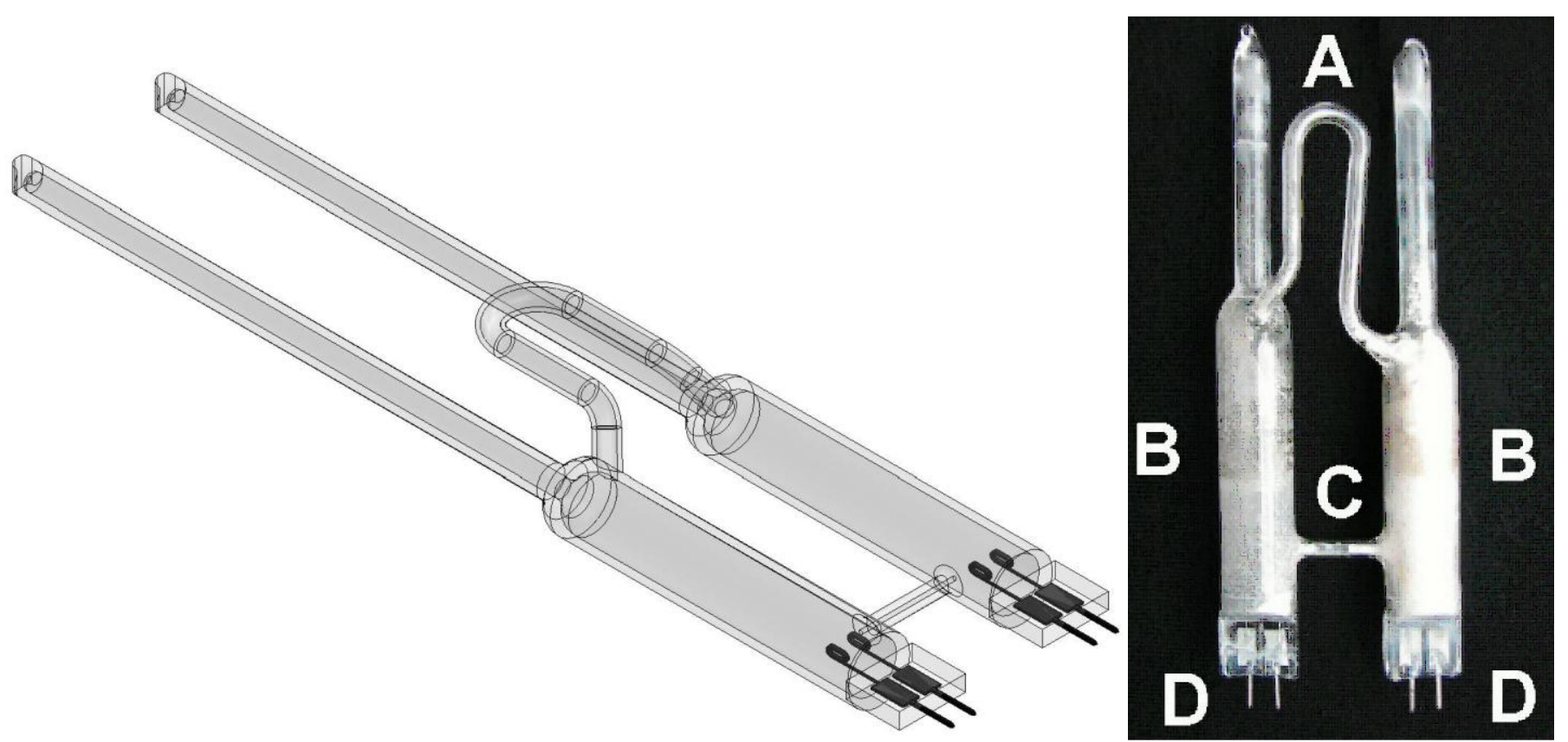

Fig. 1. Cell of fused quartz glass. To the left a drawing of new cell and to the right a photograph of a real cell sealed under vacuum after melting and refreezing. (A) - pressure equilibration tube, (B) - cell compartment, (C) - capillary tube for conduction and (D) electrode - feed throughs, adapted from standard halogen lamps. The cell is about half full of electrolyte salt.

\subsection{Measurement technique}

The resistance was obtained from impedance versus frequency diagrams measured in an AC Wheatstone bridge setup (Princeton Applied Research VersaStat 4 potentiostat with VersaStudio software, at accuracy $\approx 0.1 \%$ ). The melt conductivity (in units of S $\mathrm{cm}^{-1}$ or $\Omega^{-1} \mathrm{~cm}^{-1}$ at a particular temperature) was obtained from the relation $\sigma_{\text {melt }}=K / R_{\text {melt }}$. The cell constant $K$ is known for each cell after the initial measurement on the cell filled with the solution of 0.1 demal $\mathrm{KCl}$. The 2-electrode setup was used for measurements and electrodes were plugged into the VersaStat 4 potentiostat using shielded electric wires and data was obtained as impedance versus frequency curves (examples shown in Fig. 2). Each pair of contacts on each of the compartments was shorted in all the experiments. The lowest point on each impedance curve was used for the further data treatment. This point gives directly the real resistance $R$ for the liquid at the given temperature. Several measurements at the same temperature, performed at different time might vary within $0.5-1 \%$ due to the tendency for the liquid to form small bubbles in the capillary tube. Bubbles could be easily removed using the rocking feature of the employed furnace (which is depicted in Fig. 3). Therefore, several measurements were performed at the same conditions for each composition to insure that measurements are done in conditions with the ultimately minimized amount of bubbles. Several curves were obtained at each temperature and those giving the lowest $\mathrm{R}$ corresponding to the highest conductivity were selected as the true measurements. Knowing the resistance $R_{K C l}$ and the conductivity for the $0.1 \mathrm{D} \mathrm{KCl}$ solution at a precisely known temperature $K=R_{K C l} * \sigma_{K C l}$ can be calculated, which stays constant for the cell. After this, the cell needs to be washed with ultrapure water and dried before filling with compounds. The determination of the resistance for the electrolytes is done in the same way and, knowing $K$, we can calculate the conductivity as: $\sigma_{\text {cell }}=K / R_{\text {Cell }}$. No correction was applied for the temperature dependence of the cell constant since the expansion of fused quartz is negligibly small, and the error by ignoring this is less than $\sim 0.01 \%$.

The materials that made up the melts were weighed and transferred quantitatively into the measuring cell, which was sealed under vacuum (<0.1 Torr). Each cell was equilibrated in a rocking furnace (Fig. 3), similar to one used in our previous research [15]. Equilibration was performed at first at $280^{\circ} \mathrm{C}$ (above the melting point) for several days. Temperatures for each data point were determined with 4-wire-Pt-100- $\Omega$ resistors to a precision better than $\sim 0.5^{\circ} \mathrm{C}$. The compositions were not corrected for the minute amounts of water lost to the gas phase. Other experimental details (furnace, etc.) have been described elsewhere [12, 15]. 


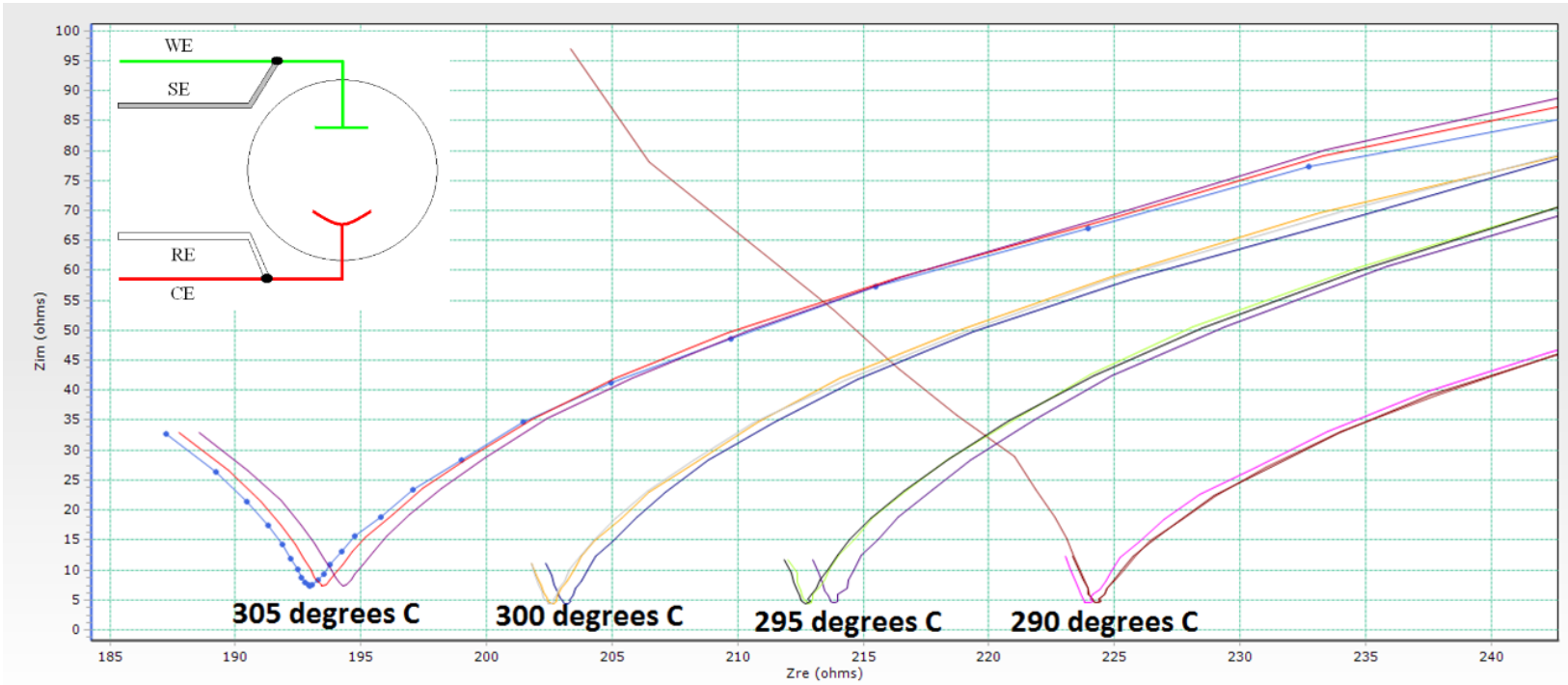

Fig. 2. Examples of impedance measurements on a cell with pure molten $\mathrm{KH}_{2} \mathrm{PO}_{4}$ at different temperatures. Inserted diagram: WE $=$ working electrode, $\mathrm{SE}=$ sense electrode, $\mathrm{RE}=$ reference electrode, $\mathrm{CE}=$ counter electrode terminals of the VersaStat 4 potentiostat.

Examples of impedance measurements on a cell with pure molten $\mathrm{KH}_{2} \mathrm{PO}_{4}$, at different temperatures are presented in Fig. 2. Each impedance point is a function of the frequency of the alternating current supplied from the VersaStat 4 potentiostat terminals to the cell. The coordinates of an actual point are the real and imaginary parts of the impedance of the cell at that frequency. The abscissa of the lowest point is taken as the cell real resistance $\mathrm{R}$ from which the conductivity is calculated as $\sigma_{\mathrm{melt}}=\sigma_{\mathrm{KCl}}$ $\mathrm{R}_{\mathrm{KCl}} / \mathrm{R}_{\mathrm{melt}}$.

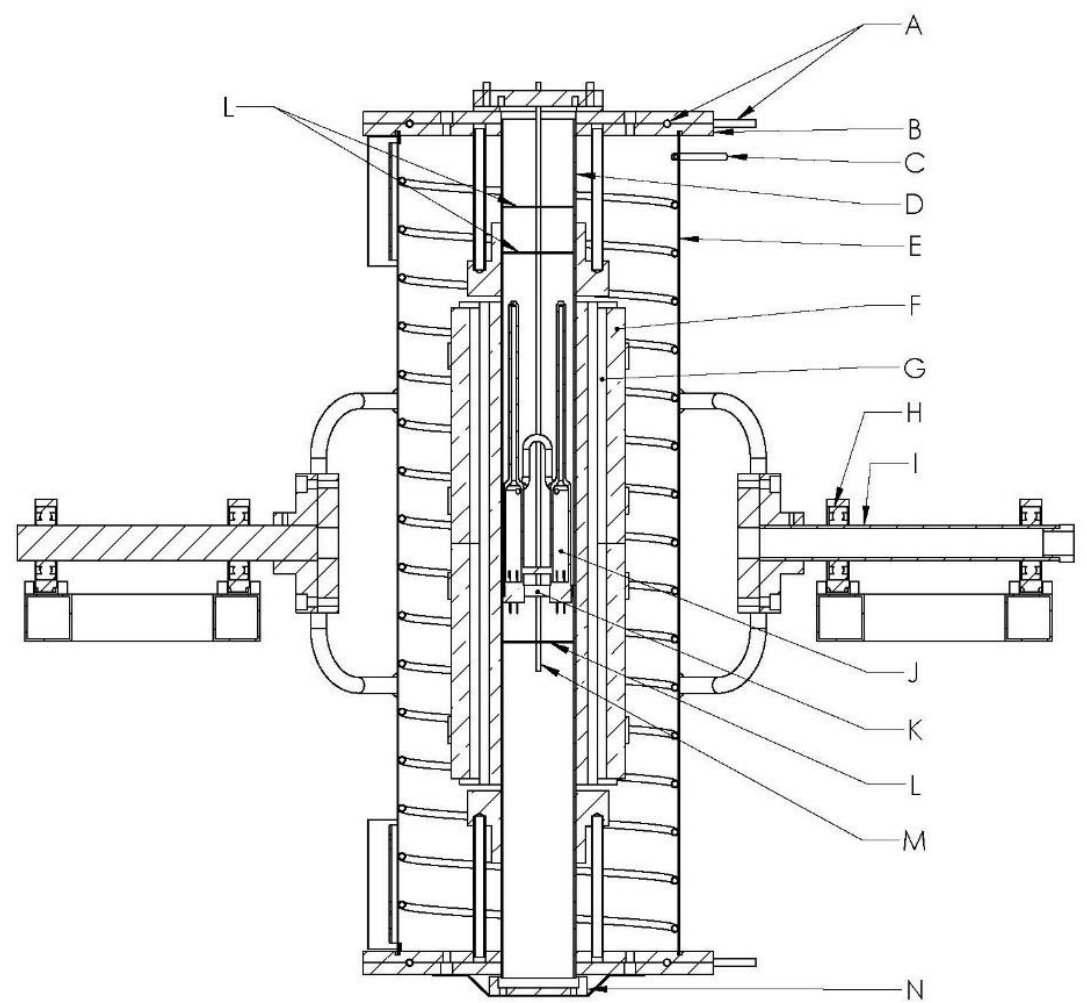

Fig. 3. Rocking furnace used for the conductivity measurements: A - Copper cooling coil; B - End plate from aluminum; C Water-cooled brass jacket; E - Thorough-going stainless steel tube F - Aluminum-bronze alloy block; G - Cooling hole for compressed air; H - Ball bearing for rocking; I - Hollow Shaft; J - Conductivity cell of fused quartz glass (Fig. 1); K Aluminum holder for the conductivity cell; L - Plate heat shields of stainless steel; $\mathrm{M}$ - Temperature sensor; $\mathrm{N}$ - Aluminum bottom plate. 
A Netzsch STA 409 PC (TG/DSC) instrument allowing for sealable high-pressure sample crucibles of chrome nickel steel (AISI $316 \mathrm{~L}$ ) and sealing discs, all with gold-plated surface (product number 6.239.2-92.31.00) be used to determine the melting point of pure $\mathrm{KH}_{2} \mathrm{PO}_{4}$. The crucibles were of bottom nominal width $6 \mathrm{~mm}$, with a volume of $27 \mu \mathrm{l}$, with maximum internal pressure of 100 bar and a maximum temperature of $500{ }^{\circ} \mathrm{C}$. After filling with about $10-50 \mathrm{mg}$ of salt, the crucibles were closed with sealing disks using a sealing press (product number 6.239.2-92.4), provided by the Netzsch Group. Also a closed cryoscopic cell sealed under vacuum was used as described earlier [16]. The Netzsch crucibles were about $30 \%$ full and the cryoscopic cell was nearly full of salt during the determinations.

\section{Results and Discussion}

The melting point was determined to be about $272 \pm 1{ }^{\circ} \mathrm{C}$ in a cryoscopic experiment for the very full sealed cell (content ca. 20 g). By the Differential Scanning Calorimetry (DSC) the melting point peak could be determined with higher precision and was found as well to be around $272{ }^{\circ} \mathrm{C}$, as is depicted in Fig. 4. The large peak is the melting point signal. More peaks were seen at lower temperatures $\left(180-240{ }^{\circ} \mathrm{C}\right)$. These peaks are attributed to the well-known solid state phase transitions in the $\mathrm{KH}_{2} \mathrm{PO}_{4}$ salt and are discussed elsewhere [3].

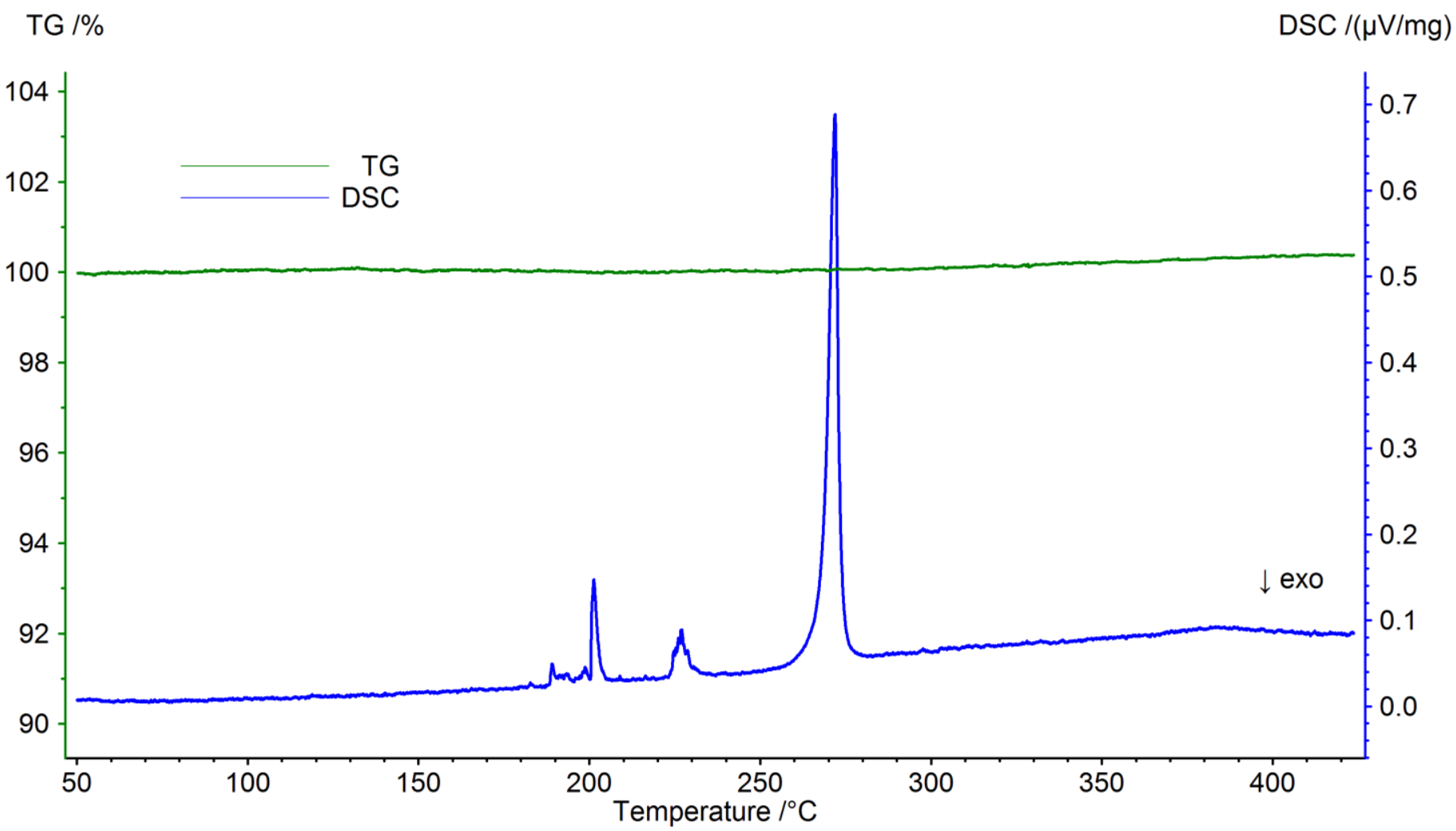

Figure 4. Differential Scanning Calorimetry plot for pure $\mathrm{KH}_{2} \mathrm{PO}_{4}$ in a closed goldplated crucible containing $15 \mathrm{mg}$ of the compound in air. No loss of weight is seen in the thermogravimetric curve.

The electrical conductivities of the pure molten $\mathrm{KH}_{2} \mathrm{PO}_{4}$ salt and four mixtures with more and less water $\left(\mathrm{KH}_{2} \mathrm{PO}_{4}-\mathrm{H}_{2} \mathrm{O}\right.$ and $\mathrm{KH}_{2} \mathrm{PO}_{4}-\mathrm{KPO}_{3}$ systems correspondingly) were obtained in units $\mathrm{S} \mathrm{cm}^{-1}$.

The following relations were used to determine the conductivity, based on the calibration with the $\mathrm{KCl} 0.1$ Demal solution [13]:

$$
\begin{aligned}
& \sigma_{\text {melt }} / \sigma_{\mathrm{KCl}}=\mathrm{R}_{\mathrm{KCl}} / \mathrm{R}_{\text {melt }} \\
& \sigma_{\text {melt }} \mathrm{R}_{\text {melt }}=\mathrm{K}=\sigma_{\mathrm{KCl}} \mathrm{R}_{\mathrm{KCl}} \\
& \sigma_{\text {melt }}=\sigma_{\mathrm{KCl}} \mathrm{R}_{\mathrm{KCl}} / \mathrm{R}_{\text {melt }}
\end{aligned}
$$


The specific electrical conductivities of bubble free melts measured versus temperature and composition are shown in Table 2.

The values of the conductivities are shown for the different compositions at 4 temperatures $\left(290,295,300\right.$ and $\left.305{ }^{\circ} \mathrm{C}\right)$. Data for the pure $\mathrm{KH}_{2} \mathrm{PO}_{4}$ are directly observed experimentally, while values for the rest of the compounds were calculated following the conductivity slope by fitting the data as shown in Table 3.

The obtained data are also presented in Fig. 5 as points along 5 curves, obtained by plotting the logarithm of the conductivity (ln $\sigma$ ) on the left ordinate scale as a function of 1000/T (the reciprocal of the absolute temperature $T$ times 1000). The linear development of the dependences follows the elementary equation of ionic conductors:

$$
\rho=\rho_{0} \exp (E / 2 k T)
$$

, where $\rho$ is the resistivity at the absolute Kelvin temperature $T, \rho_{0}$ is a constant, $k$ is the Boltzmann's constant and $E$ is the activation energy for the conduction process [4]. As the curves on Fig. 5 are approximately linear; i. e. the $\sigma$ data can be reproduced by (7):

$$
\log _{10} \sigma=A-B \times 1000 / T
$$

, with the obtained parameters $A$ and $B$ given in Table 3. The conductivity (6) decreases with addition of $\mathrm{KPO}_{3}$ (or the loss of water in open cells) and increases with temperature in the whole range of temperatures in these series. The studied compositions and temperature ranges were limited by the crystallization points of the compounds and the water vapor pressures above the compounds, which depended markedly on the temperature (possible risk of cell explosion at elevated temperatures/pressures) [3]. During standing, the viscosity and surface tension of the melt increased significantly, judging from visual observations when shaking the melts in the cell - which could be due to partly dissolution of $\mathrm{SiO}_{2}$ from the quartz in the melts.

\begin{tabular}{|c|c|c|c|c|c|c|c|c|c|c|}
\hline \multirow[t]{2}{*}{$t,{ }^{\circ} \mathrm{C}$} & \multicolumn{2}{|c|}{$\begin{array}{c}\text { Mol \% in } \\
\text { composition }\end{array}$} & \multicolumn{2}{|c|}{$\begin{array}{c}\text { Mol \% in } \\
\text { composition }\end{array}$} & \multicolumn{2}{|c|}{$\begin{array}{c}\text { Mol \% in } \\
\text { composition }\end{array}$} & \multicolumn{2}{|c|}{$\begin{array}{c}\text { Mol \% in } \\
\text { composition }\end{array}$} & \multicolumn{2}{|c|}{$\begin{array}{c}\text { Mol \% in } \\
\text { composition }\end{array}$} \\
\hline & $\mathrm{KH}_{2} \mathrm{PO}_{4}$ & $\mathrm{H}_{2} \mathrm{O}$ & $\mathrm{KH}_{2} \mathrm{PO}_{4}$ & - & $\mathrm{KH}_{2} \mathrm{PO}_{4}$ & $\mathrm{KPO}_{3}$ & $\mathrm{KH}_{2} \mathrm{PO}_{4}$ & $\mathrm{KPO}_{3}$ & $\mathrm{KH}_{2} \mathrm{PO}_{4}$ & $\mathrm{KPO}_{3}$ \\
\hline & 96.77 & 3.23 & 100 & - & 95.29 & 4.71 & 90.95 & 9.05 & 83.16 & 16.84 \\
\hline & \multicolumn{2}{|c|}{$\sigma, S \mathbf{c m}^{-1}$} & \multicolumn{2}{|c|}{$\sigma, S \mathbf{c m}^{-1}$} & \multicolumn{2}{|c|}{$\sigma, S \mathbf{c m}^{-1}$} & \multicolumn{2}{|c|}{$\sigma, S \mathbf{c m}^{-1}$} & \multicolumn{2}{|c|}{$\sigma, S \mathbf{c m}^{-1}$} \\
\hline 290 & \multicolumn{2}{|c|}{0.276} & \multicolumn{2}{|c|}{0.264} & \multicolumn{2}{|c|}{0.244} & \multicolumn{2}{|c|}{0.237} & \multicolumn{2}{|c|}{0.189} \\
\hline 295 & \multicolumn{2}{|c|}{0.291} & \multicolumn{2}{|c|}{0.278} & \multicolumn{2}{|c|}{0.257} & \multicolumn{2}{|c|}{0.250} & \multicolumn{2}{|c|}{0.202} \\
\hline 300 & \multicolumn{2}{|c|}{0.306} & \multicolumn{2}{|c|}{0.292} & \multicolumn{2}{|c|}{0.272} & \multicolumn{2}{|c|}{0.263} & \multicolumn{2}{|c|}{0.215} \\
\hline 305 & \multicolumn{2}{|c|}{0.322} & \multicolumn{2}{|c|}{0.307} & \multicolumn{2}{|c|}{0.287} & \multicolumn{2}{|c|}{0.276} & \multicolumn{2}{|c|}{0.228} \\
\hline
\end{tabular}

Table 2. Conductivities $\left(\mathrm{S} \mathrm{cm}^{-1}\right)$ at elevated temperatures as specified for $\mathrm{KH}_{2} \mathrm{PO}_{4}$, a water containing electrolyte

Table 3. Conductivity $\left(\mathrm{S} \mathrm{cm}^{-1}\right)$ expressions for different electrolyte compositions. Discussion of such expressions can be referred to elsewhere [12]. $\mathrm{R}^{2}$ value equals 1 for a perfect linear fit.

\begin{tabular}{cccc}
\hline Melt & Intercept $\boldsymbol{A}$ & Slope $\boldsymbol{B}$ & $\mathbf{R}^{\mathbf{2}}$ \\
\hline$\sim 97 \mathrm{~mol} \% \mathrm{KH}_{2} \mathrm{PO}_{4}+\sim 3 \mathrm{~mol} \% \mathrm{H}_{2} \mathrm{O}$ & $2.03465 \pm 0.04593$ & $-1.46097 \pm 0.02574$ & 0.99598 \\
$\sim 100 \% \mathrm{KH}_{2} \mathrm{PO}_{4}$ & $1.91481 \pm 0.01797$ & $-1.40371 \pm 0.01025$ & 0.99984 \\
& & & \\
& & & 0.99949 \\
$\sim 83 \mathrm{~mol} \% \mathrm{KH}_{2} \mathrm{PO}_{4}+\sim 17 \mathrm{~mol} \% \mathrm{KPO}_{3}$ & $2.40111 \pm 0.01329$ & $-1.75924 \pm 0.00727$ & 0.99843 \\
$\sim 91 \mathrm{~mol} \% \mathrm{KH}_{2} \mathrm{PO}_{4}+\sim 9 \mathrm{~mol} \% \mathrm{KPO}_{3}$ & $1.93817 \pm 0.03097$ & $-1.44330 \pm 0.01723$ & 0.99678
\end{tabular}


1

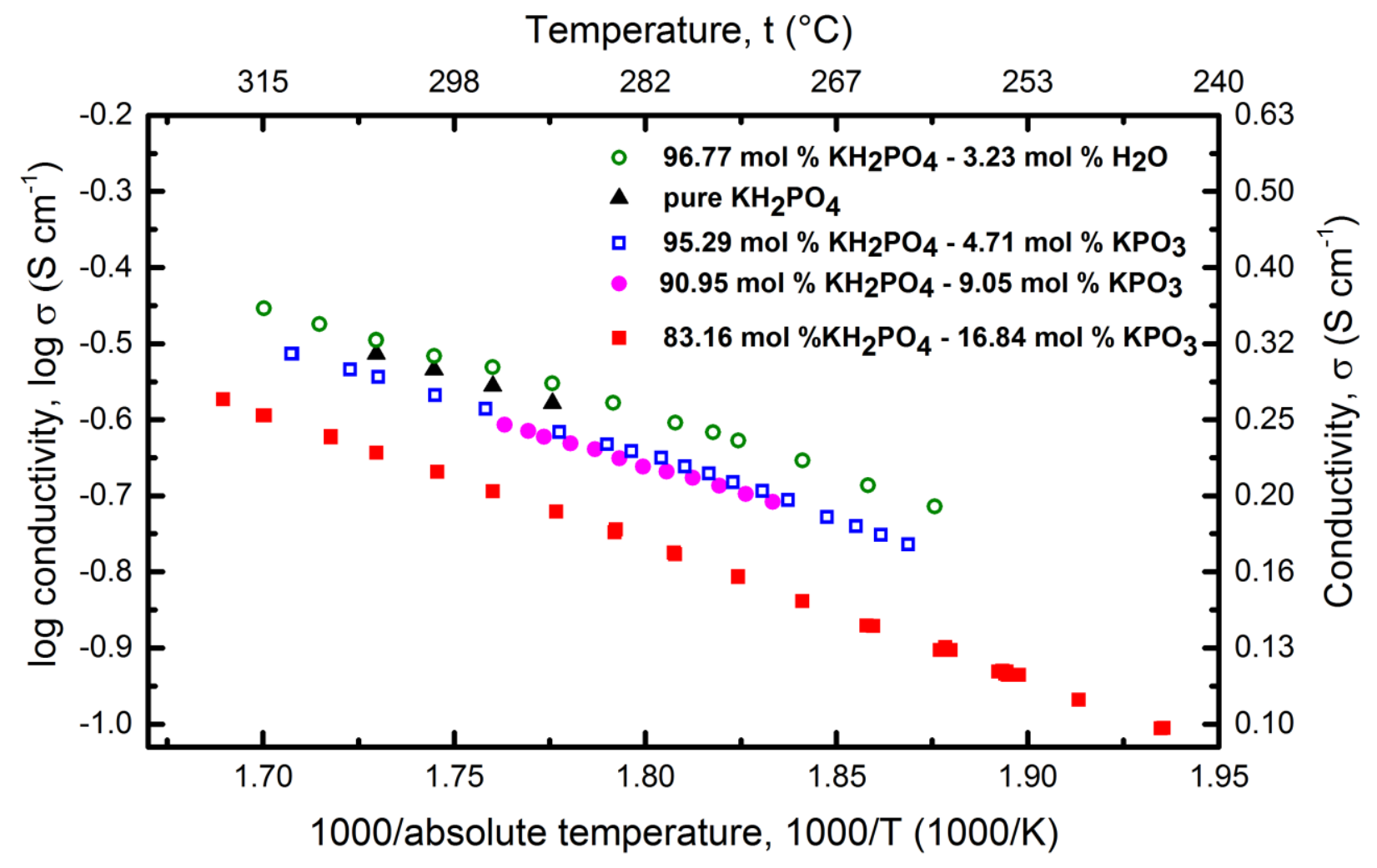

Fig. 5. The specific electrical conductivities of 5 compositions vs. temperature.

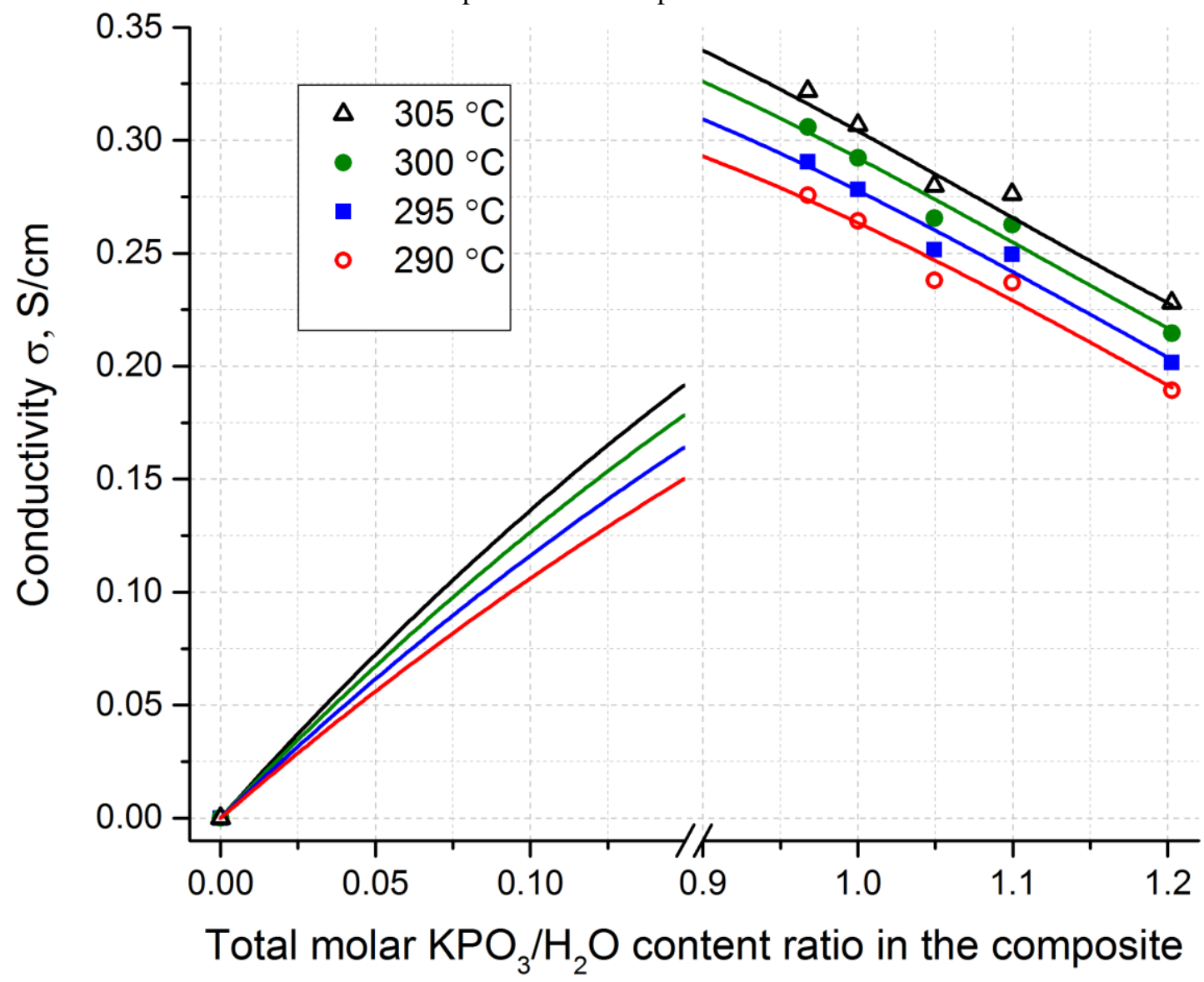

Fig. 6. Dependence of conductivity on composition of melts at different temperatures, projected to " 0 " in $\mathrm{KPO}_{3} / \mathrm{H}_{2} \mathrm{O}$ content. 
In Fig. 6 trends of change in conductivity, depending on composition of the melt, projected to " 0 " in $\mathrm{KPO}_{3} / \mathrm{H}_{2} \mathrm{O}$ content ratio are shown. A non-linear polynomial cubic function $\mathrm{y}=\mathrm{A}+\mathrm{Bx}+\mathrm{Cx}^{2}+\mathrm{Dx}^{3}$ was applied to make the projection to the " 0 "-" 0 " point: The parameters for the fitting at different temperatures can be found in Table 4. It must be outlined that measurements of conductivity in the region of the molar ratio $\mathrm{KPO}_{3} / \mathrm{H}_{2} \mathrm{O}$ below value 1 are limited due to the used apparatus - a quartz cell. As it was shown in previous work [3], the vapor pressure of the pure $\mathrm{KH}_{2} \mathrm{PO}_{4}$ is around 8 bars at $300{ }^{\circ} \mathrm{C}$, which is rather high for the cell, made of quartz. Eventually, the excess of water will increase the vapour pressure at the same given temperature. Using the mixture of $96.77 \mathrm{~mol} \%$ of $\mathrm{KH}_{2} \mathrm{PO}_{4}$ and $3.23 \mathrm{~mol} \%$ of $\mathrm{H}_{2} \mathrm{O}$, which corresponds to the value 0.97 on the $\mathrm{x}$ axis in the Fig. 5 was probably rather close to the cell's permissible pressure. Therefore, fulfilling investigation of the area of conductivities between " 0 " and " 0.97 " values in $\mathrm{KPO}_{3} / \mathrm{H}_{2} \mathrm{O}$ molar content ratio would require significant modification of the design and materials to be used to build another conductivity cell, which could tolerate such high water vapor pressures.

Table 4. Fitting parameters, used in Fig. 5 for data, obtained at different temperatures:

\begin{tabular}{|c|c|c|c|c|c|c|c|c|c|c|c|}
\hline \multicolumn{12}{|c|}{ Temperature } \\
\hline \multicolumn{3}{|c|}{290} & \multicolumn{3}{|c|}{295} & \multicolumn{3}{|c|}{300} & \multicolumn{3}{|c|}{305} \\
\hline Values & & $\begin{array}{c}\text { Standard } \\
\text { error }\end{array}$ & Values & & $\begin{array}{c}\text { Standard } \\
\text { error }\end{array}$ & Values & & $\begin{array}{c}\text { Standard } \\
\text { error }\end{array}$ & Values & & $\begin{array}{c}\text { Standard } \\
\text { error }\end{array}$ \\
\hline A & $4.09 * 10^{-6}$ & 0.01 & A & $4.08 * 10^{-6}$ & 0.01 & A & $4.20 * 10^{-6}$ & 0.01 & A & $4.27 * 10^{-6}$ & 0.01 \\
\hline $\mathrm{B}$ & $1.18 * 10^{0}$ & 0.73 & $\mathrm{~B}$ & $1.30 * 10^{0}$ & 0.72 & B & $1.42 * 10^{0}$ & 0.71 & B & $1.53 * 10^{0}$ & 0.79 \\
\hline $\mathrm{C}$ & $-1.25 * 10^{0}$ & 1.34 & $\mathrm{C}$ & $-1.43^{*} 10^{0}$ & 1.32 & $\mathrm{C}$ & $-1.61 * 10^{0}$ & 1.30 & $\mathrm{C}$ & $-1.78 * 10^{0}$ & 1.46 \\
\hline D & $3.33 * 10^{-1}$ & 0.61 & D & $4.03 * 10^{-1}$ & 0.61 & D & $4.77 * 10^{-1}$ & 0.60 & D & $5.50 * 10^{-1}$ & 0.67 \\
\hline $\begin{array}{l}\text { Redu- } \\
\text { ced } \chi^{2}\end{array}$ & \multicolumn{2}{|c|}{$7.31 * 10^{-5}$} & $\begin{array}{l}\text { Redu- } \\
\text { ced } \chi^{2}\end{array}$ & \multicolumn{2}{|c|}{$7.15^{*} 10^{-5}$} & $\begin{array}{l}\text { Redu- } \\
\text { ced } \chi^{2}\end{array}$ & \multicolumn{2}{|c|}{$6.92 * 10^{-5}$} & $\begin{array}{l}\text { Redu- } \\
\text { ced } \chi^{2}\end{array}$ & \multicolumn{2}{|c|}{$8.70 * 10^{-5}$} \\
\hline Adj. $\mathrm{R}^{2}$ & \multicolumn{2}{|c|}{$3.33 * 10^{-1}$} & Adj. $\mathrm{R}^{2}$ & \multicolumn{2}{|c|}{$9.94 * 10^{-1}$} & $\begin{array}{l}\text { Adj. } \\
\mathrm{R}^{2}\end{array}$ & \multicolumn{2}{|c|}{$9.95 * 10^{-1}$} & $\begin{array}{l}\text { Adj. } \\
\mathrm{R}^{2}\end{array}$ & \multicolumn{2}{|c|}{$9.94 * 10^{-1}$} \\
\hline
\end{tabular}

\section{Conclusions}

Conductivity of 5 systems $\left(\mathrm{KH}_{2} \mathrm{PO}_{4}, \mathrm{KH}_{2} \mathrm{PO}_{4}-\mathrm{H}_{2} \mathrm{O}\right.$ and $\left.\mathrm{KH}_{2} \mathrm{PO}_{4}-\mathrm{KPO}_{3}\right)$ was investigated at temperatures of $240-320^{\circ} \mathrm{C}$ and under their own water vapor pressures. Molten monobasic potassium phosphate, $\mathrm{KH}_{2} \mathrm{PO}_{4}$ represents a liquid with high conductivity of $\sim 0.30 \mathrm{~S} \mathrm{~cm}^{-1}$ at $300^{\circ} \mathrm{C}$. The results show significance for the potential applicability of KDP as an electrolyte, essentially in systems, where an excess of water is involved, e.g. water electrolysis systems. A new potentially highly efficient electrolyte for intermediate temperature pressurized water electrolysis has thus been found, proposing great perspectives for development of better medium temperature water electrolysis systems.

\section{Acknowledgements}

This investigation has been supported by the Danish National Advanced Technology Foundation, grant.nr. 068-2011-1 and the Danish Council for Strategic Research (Medium Temperature Water Electrolysers (MEDLYS)), grant no. 10-093906. We would like to thank Larisa Seerup for performing the Differential Scanning Calorimetry measurements and Jan Patrick Scholer for making the quartz cells by glass blowing. 


\section{REFERENCES}

[1] Cai W, Katrusiak A. Structure of high-pressure phase $\mathrm{KH}_{2} \mathrm{PO}_{4}$. Dalton Trans. 2013;42:863-6.

[2] Nikiforov AV, Petrushina IM, Jensen JO, Bjerrum NJ. Corrosion behavior of construction materials for intermediate temperature steam electrolysers. Advanced Materials Research. 2013;699:596-605. Presented at: 2013 International Conference on Materials Science and Chemical Engineering (MSCE 2013), Singapore. http://dx.doi.org/10.4028/www.scientific.net/AMR.699.596.

[3] Berg RW, Nikiforov AV, Petrushina IM, Bjerrum NJ. Determination of water vapor pressure over molten $\mathrm{KH}_{2} \mathrm{PO}_{4}$ and demonstration of water electrolysis in that melt at $\sim 300{ }^{\circ} \mathrm{C}$ by means of Raman spectroscopy. To be submitted to EEST2015 Special issue of Applied Energy, 2015.

[4] Farag HI, Elmanharawy MS, Abdel-Kader A. Some Temperature Dependent Properties of Potassium Dihydrogen Phosphate. Acta Physica Hungarica. 1986;60 (1-2):19-30. Springer-Verlag. http://dx.doi.org/10.1007/bf03157413.

[5] Kiehl SJ, Wallace GH. The dissociation pressures of monopotassium and monosodium orthophosphates and of dipotassium and disodium dihydrogen pyrophosphates. Phosphate IV. J. Am. Chem. Soc. 1927;49:375-86.

[6] Subramony JA, Lovell S, Kahr B. Polymorphism of Potassium Dihydrogen Phosphate. Chemistry of Materials. $1998 ; 10$ (8): 2053-7. http://dx.doi.org/10.1021/cm980293j.

[7] Safety Data Sheet (SDS) for potassium dihydrogen phosphate (CAS: 7778-77-0), according to Regulation (EC) No. 453/2010, Version 5.5 Revision Date 02.09.2015, by 19.11.2015, provided by Sigma Aldrich for P0662.

[8] Perry DL. Handbook of Inorganic Compounds, 553 pages, Publisher: Taylor \& Francis. ISBN: 1439814619, 9781439814611, 2011.

[9] Lewis RJ, Ed. Hawley's Condensed Chemical Dictionary, 12th ed. New York: Van Nostrand Reinhold Co.; 1993.

[10] O'Keeffe M, Perrino CT. Proton conductivity in pure and doped $\mathrm{KH}_{2} \mathrm{PO}_{4}$. J. Phys. Chem. Solids. 1967; 28(2): 211-8. http://dx.doi.org/10.1016/0022-3697(67)90110-2.

[11] Merz AR. Note on Monopotassium Phosphate. J. Am. Chem. Soc., 1927, 49 (6), pp 1511-2.

[12] Hjuler HA, Berg RW, Zachariasen K, Bjerrum NJ. Specific Conductivity of $\mathrm{NaCl}-\mathrm{AlCl}_{3}$ and $\mathrm{NaCl}-\mathrm{AlCl}_{3}-\mathrm{Al}_{2} \mathrm{~S}_{3} \mathrm{Melts.} \mathrm{J.}$ Chem. Eng. Data. 1985; 30:203-8.

[13] Jones G, Bradshaw BC. The measurement of the conductance of electrolytes. V. A redetermination of the conductance of standard potassium chloride solutions in absolute units. J. Am. Chem. Soc. 1933; 55:1780-800.

[14] Berg RW, Hjuler HA, Bjerrum NJ. Cryoscopy in the $\mathrm{KCl}-\mathrm{AlC1}_{3}$ system. High precision phase diagram near equimolar composition, with comments on oxide contaminations and effective chloride concentrations in tetrachloroaluminate melts. Inorg. Chem. 1985; 24: 4506-11.

[15] Andreasen HA, Bjerrum NJ, Foverskov CE. Automated "float" method for determination of densities of molten salts. Review of Scientific Instruments. 1977; 48:1340. http://dx.doi.org/10.1063/1.1134884.

[16] Berg RW, Hjuler HA, Bjerrum NJ. Phase diagram of the $\mathrm{NaCl}-\mathrm{AlCl}_{3}$ system near equimolar composition, with determination of the cryoscopic constant, the enthalpy of melting and oxide contaminations. Inorg. Chem. 1984; 23:557-65. 